\title{
36. THE CENOZOIC OSTRACODE FAUNAS OF THE SAO PAULO PLATEAU AND THE RIO GRANDE RISE (DSDP LEG 39, SITES 356 AND 357)
}

\author{
Richard H. Benson, Smithsonian Institution, Washington, D.C.
}

Forty-eight samples were examined from two sites (356 and 357) of DSDP Leg 39 from calcareous layers ranging in age from Maestrichtian (Site 356) and Danian (Site 357) to late Neogene. Ostracodes were found in almost all samples ( $20 \mathrm{cc}$ in size), with 634 specimens identified. The samples were small and the number of specimens would have been considered less than adequate, except for the ability to compare them with the plentiful and complementary assemblages of Sites 21, 21A, and 22 (Maxwell et al., 1970).

The 28 samples examined from Site 357 had better preserved and more abundant specimens than those of Site 356 , possibly due to somewhat shallower conditions or a difference in sediment permeability. The total number of taxa identified from all samples, for the most part to the generic level, is less than 25 . In no single sample were there more than 10 species; most samples had 5 or less.

As stated in another recent preliminary report (Benson, 1974), the ostracodes of the deep sea are still in the beginning stages of study. However, in spite of the lagging formal description of many of the new taxa, both morphologic and faunal trends are known (Benson, 1975a; Sylvester-Bradley and Benson, 1971). Several new taxa are described for the first time in this report. Tentative names of yet undescribed taxa are given in quotes. A census of the assemblages follows:

$$
\begin{gathered}
\text { Identification of Ostracode Taxa } \\
\text { by Site and Sample }
\end{gathered}
$$

Site $356\left(28^{\circ} 17.22^{\prime} \mathrm{S}, 41^{\circ} 05.28^{\prime} \mathrm{W} ; 3175 \mathrm{~m}\right)$

Sample 2-4, 24-26 cm; Plio-Pleistocene, N19-22:

Poseidonamicus pintoi?

Krithe sp. 1

Henryhowella asperrima

Sample 3-4, 31-33 cm; Plio-Pleistocene, N19-22:

Krithe sp. 1

"Pelecocythere galitea"?

Sample 4-4, 41-43 cm; Plio-Pleistocene, N19-22:

Krithe sp. 1

Poseidonamicus major

Henryhowella asperrima

Sample 5-5, 41-43 cm; early Miocene, N4:

Krithe sp. 1

Poseidonamicus major

Bairdia sp.

Cytherella ovata?

"Thalassocythere" acanthoderma (Brady) (no adults)

Henryhowella asperrima
Sample 6-3, 41-43 cm; Eocene, P12:

unidentified

Sample 8-2, 41-43 cm? middle Eocene, P10-11: Krithe sp.

Sample 9-2, 134-136 cm; middle Eocene, P9-10: by thocyprids

Krithe sp.

Bairdia sp.

Cytherella ovata

Henryhowella instar

Sample 10-3, 46-48 cm; early Eocene, P8-9: "Oxycythereis" sp.

Sample 12-2, 40-42 cm; early Eocene, P7: Krithe? sp.

Sample 14-1, 143-145 cm; early Eocene, P6-8: by thocyprids

Sample 16-2, 82-84 cm; Paleocene-Eocene: bythocyprids

Sample 22-3, 87-89 cm; late Paleocene, P4: Bairdia instar

Sample 23-3, 64-66 cm; late Paleocene, P3: Krithe sp.

Phacorhabdotus subtridentus Benson, n. sp.

Sample 24-4, 94-96 cm; Danian:

Macrocypris

Phacorhabdotus subtridentus?

Cytherella ovata?

Bairdia sp.

Bythocypris sp.

Sample 25-3, 86-88 cm; Danian: Atlanticythere murareticulata Benson, n. sp. Bairdia sp. Krithe sp.

Sample 26-3, 102-104 cm; Danian:

Phacorhabdotus texanus Howe and Laurencich Cytherella ovata?

by thocyprids

Sample 27-3, 89-91 cm; Danian: Krithe sp. 2

Sample 28-3, 59-61 cm; Danian:

Krithe sp.

by thocyprid $\frac{4}{4}$

2

2

1

$\frac{1}{7}$

$\frac{1}{1}$

$\frac{1}{1}$

$\frac{3}{3}$

$\frac{2}{2}$

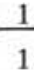

4

$\frac{1}{5}$

1

$\frac{4}{14}$

4

$\frac{2}{7}$

3

\begin{tabular}{l}
2 \\
2 \\
\hline
\end{tabular}

1
1 
Phacorhabdotus texanus?

Cytherella ovata

Bairdia sp.

cy thereisid instar

Sample 29-3, 21-23 cm; Danian:

Macrocypris

Krithe sp.

cythereisid instar

Bairdia sp.

Rocaleberis?

Sample 30-3, 84-86 cm; late Maestrichtian:

Krithe sp.

cy thereisid instar

unidentified

Site $357\left(30^{\circ} 00.25^{\prime} \mathrm{S}, 35^{\circ} 33.59^{\prime} \mathrm{W} ; 2086 \mathrm{~m}\right)$

Sample 1-3, 35-37 cm; late Pliocene, N21:

Krithe sp. 1

Krithe sp. 2

Poseidonamicus pintoi

Bradleya dictyon? instar

Sample 2-3, 33-35 cm; early Pliocene, N19:

Krithe sp. 1

Poseidonamicus pintoi

Agrenocythere sp.

Henryhowella dasyderma (Brady)

Sample 3-3, 33-35 cm; late Miocene, N17-18:

Bradleya dictyon?

Poseidonamicus major?

"Suhmicythere" sp.

Krithe sp.

Bairdia sp.

Sample 4-4, 33-35 cm; mid Miocene, N15-16: Bradleya dictyon

Poseidonamicus major?

Krithe sp.

Cytheropteron sp. instar

Henryhowella asperrima

Sample 5-3, 33-35 cm; mid Miocene, N14-15:

Bradleya dictyon

Poseidonamicus pintoi

Krithe sp.

Henryhowella asperrima

"Suhmicythere" sp.

Sample 6-3, 33-35 cm; early Miocene, N6-7

"Thalassocythere" acanthoderma? (Brady)

Poseidonamicus instars

Krithe sp. 2

Henryhowella asperrima?

Sample 7-3, 33-35 cm; early Miocene, N6-7:

Poseidonamicus pintoi?

"Thalassocythere" acanthoderma?

Krithe sp. 2

Sample 8-3, 33-35 cm; early Miocene, N5-6:

Poseidonamicus sp.

Agrenocythere hazelae

Bradleya dictyon?

"Thalassocythere" sp.?

Krithe sp.
Sample 9-3, 33-35 cm; early Miocene, N5-6:

Poseidonamicus sp.

"Thalassocythere" sp.

Krithe sp.

Sample 10-2, 33-35 cm; early Miocene, N4-5:

Poseidonamicus pintoi?

trachyleberid (poorly preserved)

Krithe sp.

Bradleya dictyon?

"Pelecocythere" sp.

Henryhowella asperrima?

Bairdia sp.

Acanthocythereis sp.

Sample 11-2, 33-35 cm; early Miocene, N4:

Henryhowella asperrima

Acanthocythereis aff. $A$. subsequenta

Poseidonamicus

Krithe sp.

Sample 12-3, 33-35 cm; early Miocene, N4: Poseidonamicus sp.

Henryhowella sp.

Krithe sp.

Sample 13-2, 33-35 cm; early Miocene, N4: Poseidonamicus sp.

Krithe sp.

bythocyprid

Sample 14-2, 33-35 cm; early Miocene, N4: broken specimen

Sample 15-2, 33-35 cm; early Miocene, N4: Ambocythere sp.

Poseidonamicus

Rocaleberis? sp.

Krithe sp.

Sample 16-2, 33-35 cm; late Oligocene, P22 (preservation poor):

Krithe sp.

Rocaleberis nascens? Bertels

Poseidonamicus

unidentified

Bairdia sp.

Bradleya sp.

Cytherella

"Oxycythereis"?

Sample 17-3, 33-35 cm; late Oligocene, P22:

Agrenocythere hazelae

Poseidonamicus

Bairdia sp.

Bradleya dictyon?

Krithe sp.

Sample 18-3, 31-33 cm; Oligocene:

Agrenocythere hazelae

Krithe sp.

Bairdia

Poseidonamicus sp.

unidentified

Sample 19-2, 50-52 cm; early Oligocene, P18-19:

Bradleya

Krithe sp.

Rocaleberis nascens? Bertels 
Sample 20-2, 145-147 cm; late Eocene, P16-17: Krithe sp.

Atlanticythere murareticulata $\mathrm{n} . \mathrm{sp}$.

Rocaleberis nascens? Bertels

Brachycythere instar

Cytheropteron $\mathrm{sp}$.

"Thalassocythere"

unidentified sp.

Eocytheropteron sp.

Bythocythere sp.

Bairdia sp.

Sample 21-2, 74-76 cm; middle/lower Eocene, P14-15: Atlanticythere? sp. (badly preserved)

Paleoabyssocythere (grossly reticulate)

Eocytheropteron (large)

Cytherella ovata

Cytherelloidea $\mathrm{sp}$.

Bythocythere sp.

Sample 22-3, 81-83 cm; middle Eocene, P11-14:

Atlanticythere? eocenica Benson, n. sp.

Trachyleberis?

Cytherella sp.

Cytherelloidea sp.

Krithe sp.

Sample 23-3, 45-57 cm; middle Eocene, P11-14:

Krithe sp.

Cytherella sp.

Bairdia sp.

Bradleya

Agrenocythere hazelae

Sample 25, CC; middle Eocene, P11-12:

Krithe sp.

Bairdia sp.

Sample 26-3, 49-51 cm; middle Eocene, P11-12: Atlanticythere eocenica

Krithe sp.

bythocyprid

Sample 27-3, 79-91 cm; early Eocene, P8:

Atlanticythere eocenica?

bythocyprid

Krithe sp.

Sample 28-3, 62-64 cm; early Eocene, P8: Krithe sp.

Sample 30-3, 47-49 cm; Danian: Atlanticythere maestrichtia Benson, n. sp. Bairdia sp.

Krithe sp.

\section{COMPARISON OF TAXA AND FAUNAL ASSEMBLAGES}

Of the 23 ostracode genera that have been found in the samples of Sites 356 and 357 , all but 5 have been previously described. Two new genera, Atlanticythere and Paleoabyssocythere, will be described in a section to follow. The three remaining genera are represented by imperfectly known modern species (that is, the lectotypes have not yet been selected; fide H. S. Puri, who is in the process with the British Museum in these designations). These species originally described by Brady (1880) should serve as the type-species of the new genera, for which an informal usage of the new generic names (in quotes) is given here.

The ostracode faunas of Sites 21, 21A, 22, 356, and 357 are similar at a given stratigraphic horizon for that portion of the section where there are samples in common. The greatest change with time takes place in late Eocene or early Oligocene. Ornate ostracodes such as Atlanticythere and Paleoabyssocythere end or evolve rapidly into new forms at this time. They have remained morphologically stable since the Campanian, except for an increased degree of secondary reticulation. Phacorhabdotus, Eocytheropteron, and the presence of Cytherelloidea also terminate. After this time, the modern deep-sea ostracode fauna begins with the general cooling of the World Ocean and the formation of the psychrosphere (Benson, 1975a; Shackleton and Kennett, 1975). Among the ornate genera, Poseidonamicus, Bradleya (whose earliest record is in the middle Eocene of Site 357), "Suhmicythere" (based on Cythere suhmi Brady, 1880), "Thalassocythere" (based on Cythere acanthoderma Brady), and Henryhowella tend to dominate the new psychrospheric faunas.

Several smooth ostracodes, such as Bairdia, Cytherella, Krithe, and Bythocypris, continue on through the change. These genera are typical of deep water, but also have a broader depth range than many of the ornate genera. Their continuance indicates less reaction of these forms to new environments. These smooth ostracodes continually pose a problem of species identification for the paleontologist, yet their value as ecologic indicators is great.

The number of species present in samples from the cores from the Rio Grande Rise, or the ocean floor in general, does not increase or decrease significantly from the Cretaceous to the present, but the diversity does fluctuate identifiably near the Eocene-Oligocene boundary (Figure 1). A late Eocene sample (2-2, 145$147 \mathrm{~cm}$ ) of Site 357 contained 10 species with only 40 specimens present. In the lower Oligocene of the same site $(18-3,31-33 \mathrm{~cm})$, there were only five species with 25 specimens present. A similar decrease in number of individuals and species was indicated in cores of Sites 19 and 20 of Leg 3. Comparisons with other samples, such as one from the late Miocene of Site 357 (3-3, 33$35 \mathrm{~cm}$ ) having only five species with 46 specimens found, may indicate other periods of a possible local decline in faunal diversity. There were low diversities in the N15-16 zones of Sites 15 and 16. However, no change in faunal composition is indicated during the Neogene.

Comparison of the ostracode faunas of Sites 356 and 357 shows that of Site 356 to be very poor. Of course, much of the upper Tertiary is missing at Site 356. The late Miocene and Plio-Pleistocene samples of this site, as do those of Site 357, contain typical psychrospheric genera. The few forms that are represented in the lowermost Tertiary of Site 356 are comparable to those of the same age of Sites $21 \mathrm{~A}$ and 357.

All of these census records tend to reinforce each other. Although admittedly the amount of material from Site 356, and to a lesser degree from Site 357, was 


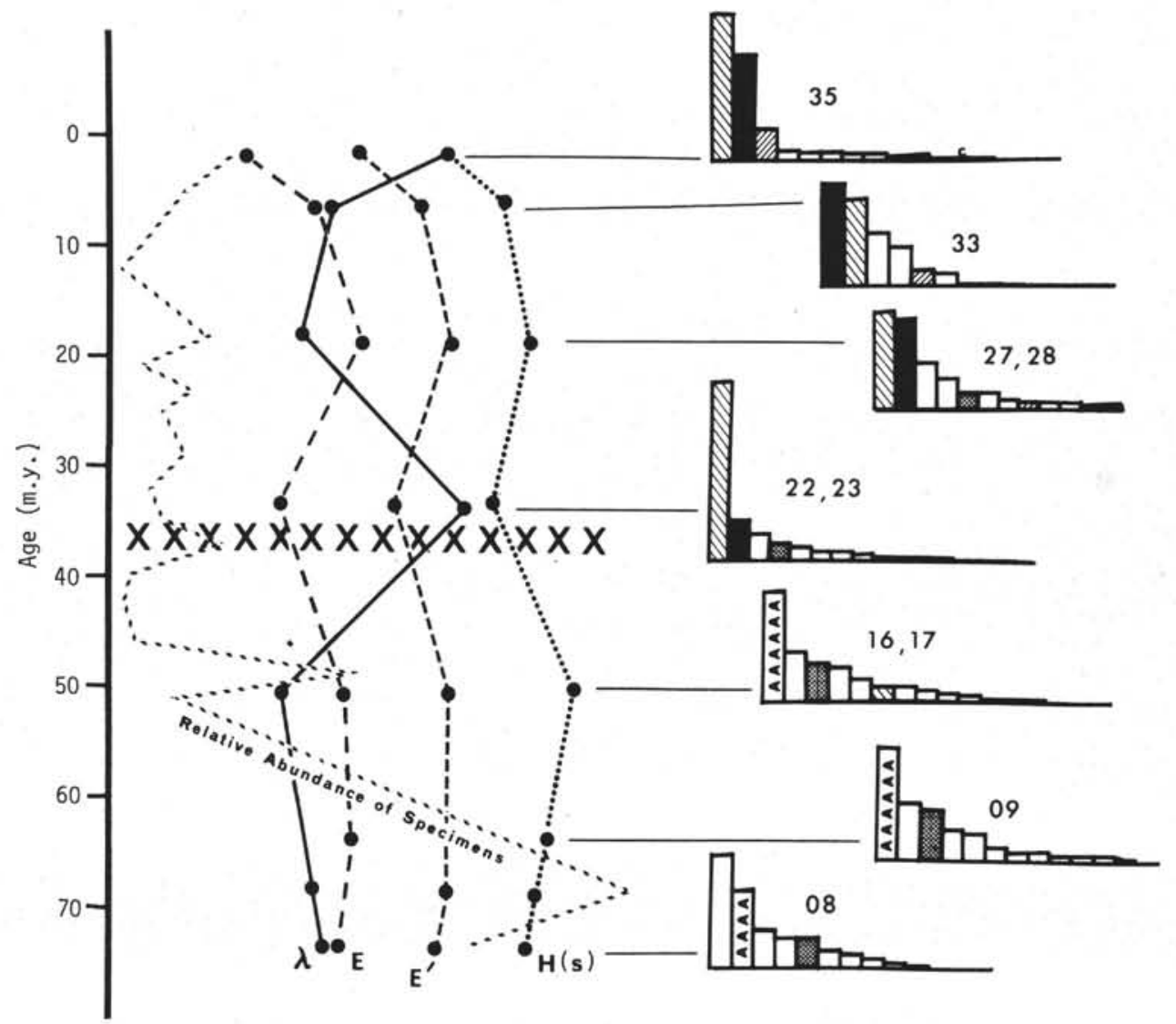

Figure 1. General changes in ostracode assemblage structure and assemblage abundance through $75 \mathrm{~m} . \mathrm{y}$. in the South Atlantic (after Benson, $1975 a, b$ ). Note (1) the striking decrease in the relative number of individuals from the early Paleogene onward, (2) the central fluctuation in the four statements of diversity at about 38 m.y.B.P. and (3) the continuity of assemblage structure as shown in the histograms from the Cretaceous through the Eocene, a great change in the Oligocene, and a stabilization in the Neogene. (The histogram identification numbers $=$ the composite foraminiferal zones as shown in Table 1.)

not as abundant as should be present for this kind of analyis, the variability of faunal composition was minimal. The overall trends of th ostracode faunal structure indicate an abrupt change from an ancestral restricted fauna to a descendant deep-sea fauna. There are only two faunas known from the overall fossil succession of the floor of the South Atlantic, and only one general fauna known from post-Eocene times from the ocean (Benson, 1975a). The taxonomic adjustments between these two faunas are reflected at Sites 356 and 357 to complement Sites 21, 21A, and 22. These in total give a relatively complete record of the transition from a deep-water (presumably stressed) thermospheric fauna to a deep-water psychrospheric fauna (Tables 1 and 2). The nature of the stressed or restricted fauna is better understood as other factors besides diversity are considered.

The Maestrichtian and Paleogene ostracode faunas of Argentina have been well described by Bertels (1973, 1974, 1975), especially from the Colorado Basin. This basin, which lies in central Argentina and was contiguous with the Atlantic, contains moderately deep water thermospheric ostracodes (as much as $500 \mathrm{~m}$ ).
During the Danian, indications of cooling are evident in changes in the fauna of the Rocanian Stage (Bertels, 1975). Some elements of this fauna may be seen in the cores of Sites 356 and 21 (a hiatus is present in Site 357). However, the ostracode faunas of the São Paulo Plateau and the Rio Grande Rise were still deeper than those of the Colorado Basin. There are few species in common (maybe Rocaleberis nascens Bertels), although several genera are the same (Krithe, Cytherella, Bythocythere, Phacorhabdotus, Bythocypris?). Among the ornate species, those of the Colorado Basin are notably more massive in architecture and their ancestry can be traced (except perhaps for the species of Rocaleberis and Wichmannella) into known shelf depth species (of the genus "Costa," Actinocythereis, Munseyella, and Buntonia).

This Argentine fauna is interesting for its differences with the deeper fauna, and these differences should not go unnoticed. First, this shallower fauna is probably the one that would be present if the Rio Grande Rise had been shallow during the late Cretaceous and early Paleogene; and secondly, a lowering of temperatures is noticed even in shelf areas during the Danian. This 
TABLE 1

Composite Foraminiferal Zones

\begin{tabular}{|c|c|c|}
\hline $\begin{array}{l}\text { Youngest Age } \\
\text { (m.y.B.P.) }\end{array}$ & $\begin{array}{l}\text { New Zone } \\
\text { Number } \\
\text { Used Herein }\end{array}$ & $\begin{array}{c}\text { Planktonic Foraminiferal } \\
\text { Zones, etc. }\end{array}$ \\
\hline 0 & 35 & N21-23 \\
\hline 3 & 34 & N19-20 \\
\hline 5 & 33 & N17-18 \\
\hline 7 & 32 & N16 \\
\hline 10 & 31 & N15 \\
\hline 12 & 30 & N14 \\
\hline 14 & 29 & N9-13 \\
\hline 16 & 28 & N6-8 \\
\hline 19 & 27 & N5 \\
\hline 21 & 26 & N4 \\
\hline 22.5 & 25 & N3, P22 \\
\hline 26 & 24 & N2, P21 \\
\hline 30 & 23 & $\mathrm{~N} 1, \mathrm{P} 20$ \\
\hline 32 & 22 & P19 \\
\hline 35 & 21 & P18 \\
\hline 37.5 & 20 & P16,17 \\
\hline 41 & 19 & $\mathrm{P} 14,15$ \\
\hline 44 & 18 & P12, 13 \\
\hline 47 & 17 & $\mathrm{P} 10,11$ \\
\hline 49 & 16 & P7-9 \\
\hline 52 & 15 & P6 \\
\hline 54 & 14 & P5 \\
\hline 56 & 13 & P4 \\
\hline 58 & 12 & P3 \\
\hline 60 & 11 & $\mathrm{P} 2$ \\
\hline 62 & 10 & P1 \\
\hline 65 & 9 & Maestrichtian \\
\hline 70 & 8 & Campanian \\
\hline 76 & 7 & Santonian \\
\hline 81 & 6 & Coniacian \\
\hline 86 & 5 & Turonian \\
\hline 92 & 4 & Cenomanian \\
\hline 100 & 3 & Albian \\
\hline 106 & 2 & Aptian \\
\hline 112 & 1 & Barremian \\
\hline
\end{tabular}

latter change may portend the conditions that lead to the formation of the psychrosphere. This seems a strong extrapolation. But the ostracodes of this cooling are those that later become important ostracode genera in the psychrosphere of the southern Ocean region, and they remain without great morphologic change since the Paleogene. The lack of the presence of the uppermost slope or shelf ostracode fauna seems to refute the notion that the Rio Grande Rise was much shallower during the latest Cretaceous or Paleogene than it was subsequently.

\section{CHANGES IN OSTRACODE MORPHOLOGY}

The notation of a succession of taxa assumes considerably more importance as their evolution is shown to be tied to adaptive responses. Ostracodes live within a thermal-metabolic budget that controls the amount of calcite available for the multiple secretion (molting, ecdysis) of their exoskeleton. Among modern species, those that live in deep cold water are frequently larger in size and almost always have thinner or more delicate carapaces than their more massive warm and usually shallow-water counterparts. To compensate for both of these relative decreases in shell material, the structures that provide strength to the carapace become better organized and usually more conspicuous. These structures are often deterministic in that they totally react as a static frame. This readjustment of morphological features to fit new conditions can often be seen as increased ornamentation, even if not always understood as members of a structural system (Benson, 1975a).

The morphologic adjustments in structure between antecedent and descendant species of the pre-Oligocene fauna and the post-Eocene fauna are quite noticeable (i.e., Atlanticythere). In several cases, this difference is of generic importance (i.e., PaleoabyssocythereAbyssocythere). In view of this structural compensation, it can be stated that there is a definite trend from usage of massive amounts of material as strength to usage of "ornament" or recognizable structure for strength. This is especially notable in the increase and then dominance of reticulation and appearance of secondary reticulation. In the older fauna reticulation is subdued or absent. The shells have a massive appearance. In the younger fauna the ornate shells are reticulate, or spinose, and eventually much larger in size (Figure 2).

\section{DEPTH OF WATER}

To consider any hypothesis or argument of subsidence of the South Atlantic basins as seen through paleontological evidence, it is necessary to state a few limitations and strengths of the benthonic indicators as shown by the ostracodes.

First, the ostracodes that occur in the marine fossil record are restricted to the sea or ocean floor. They have no known pelagic larval stages. They are adapted to the conditions of the bottom; that is, to the conditions of mechanical, thermal, and biological stress. They must adapt to larger changes after the fact. The evolution occurs most quickly in the carapace design. If we could understand the statics of shell structure, which is not wholly possible yet, they should indicate in a relatively precise manner, the change in bottom water depth.

Secondly, depth from a paleontological view is seldom a direct function of changes in temperature, decreasing light, movement of water, etc. However, depth does affect ostracodes in proportion to its increase, usually in an exponential manner. Thus, in response to depth, diversity of species decreases, architecture becomes more sophisticated, shell walls thin, size increases, blindness becomes universal, many taxa change as members of assemblages, etc. Some of these changes, such as blindness and decrease in skeletal material, are direct functions of decrease in light or the lowering of temperature. The change in diversity, or presence of certain taxa may be more the result of barriers to immigration and more complex historical limitations that can be easily interpreted in the first examination of a fauna.

To conclude, from the examination of the ostracodes of Site 357 and comparison of these with the faunas of Sites $21 \mathrm{~A}$ and 22, the depths seem deeper than 1000 meters from the Danian to the present time. The faunas are totally blind (indicating probable depths greater than $800 \mathrm{~m}$ ) with generally large specimens. The low 
TABLE 2

Species - Zone Matrix: South Atlantic

Geologic Age and B-Zone

\begin{tabular}{|c|c|c|c|c|c|c|c|c|c|c|c|c|c|c|c|c|c|c|c|c|c|c|c|}
\hline \multirow[b]{2}{*}{ Taxa } & \multicolumn{2}{|c|}{ Cretaceous } & \multicolumn{2}{|c|}{$\begin{array}{l}\text { Paleo-./ } \\
\text { cene }\end{array}$} & \multicolumn{3}{|c|}{ Eocene } & & \multicolumn{3}{|c|}{ Oligocene } & \multicolumn{2}{|c|}{1} & \multicolumn{3}{|c|}{ Miocene } & \multicolumn{3}{|c|}{$\begin{array}{c}\text { Plio- } \\
\text { / Pleistocene }\end{array}$} & \multirow{2}{*}{$\begin{array}{c}\text { Total } \\
\text { Specimens }\end{array}$} & \multirow{2}{*}{$\begin{array}{l}\text { No. of } \\
\text { Samples }\end{array}$} \\
\hline & 08 & 09 & & 15 & 16 & 17 & 18 & 19 & 20 & 21 & 22 & 23 & 24 & 25 & 26 & 27 & 28 & 31 & 33 & 34 & 35 & & \\
\hline Cytherelloidea & 132 & 37 & & & & 1 & & 1 & & & & & & & & & & & & & & 169 & 8 \\
\hline Glossicythere & 6 & 73 & & & & & & & & & & & & & & & & & & & & 79 & 3 \\
\hline Atlanticythere \#1 & 91 & 151 & & & & & & & & & & & & & & & & & & & & 242 & 7 \\
\hline Cythereis & 2 & 8 & & 2 & & & & & & & & & & & & & & & & & & 12 & 5 \\
\hline Paleoabyssocythere & 19 & 13 & & & 1 & & & 1 & & & & & & & & & & & & & & 34 & 7 \\
\hline Atlanticythere \#2 & 34 & 34 & & & 17 & 67 & & & & & & & & & & & & & & & & 152 & 8 \\
\hline Atlanticythere \#3 & & 9 & & 43 & 13 & 16 & & 10 & 2 & & & & & & & & & & & & & 93 & 10 \\
\hline Rocaleberis & & 11 & & & & & & & 4 & 2 & & & & 2 & 2 & & & & & & & 21 & 6 \\
\hline Australoecia & & & 1 & & 1 & 1 & & & & & & & & & & & & & & & & 3 & 3 \\
\hline Bairdia & 10 & 27 & & 12 & 23 & 8 & 1 & 1 & 8 & 4 & 1 & 4 & 1 & 10 & 8 & & & & 3 & & 4 & 125 & 41 \\
\hline Argilloecia & 2 & 1 & & & & & & & & & & & & & & & & & & & & 3 & 3 \\
\hline Bythocypris & 41 & 11 & & 3 & 2 & 1 & & & & & & 1 & & & & & & & & & & 59 & 10 \\
\hline Cytherella & 33 & 64 & 1 & 4 & 14 & 20 & & & 1 & 10 & 4 & 2 & 3 & 2 & 6 & & 5 & & 1 & & 2 & 172 & 37 \\
\hline Trachyleberidea & 3 & & & & 3 & 14 & & & & & & & & & & & & & & & & 20 & 5 \\
\hline Cytheropteron & & 1 & & & 4 & 33 & & & 2 & 1 & & & & 1 & & & & 1 & & & 5 & 48 & 11 \\
\hline Eucythere & & & & & & & & & & & & & & & & & & 1 & 2 & & 1 & 4 & 4 \\
\hline Eocytheropteron & & & & 1 & & 8 & & & & & & & & & & & & & 1 & & 1 & 11 & 4 \\
\hline Mesocythereis & & & & 5 & 1 & 1 & & & & & & & & 1 & & 1 & 1 & & & & & 10 & 6 \\
\hline Oxycythereis & & & & & 2 & & & 1 & & 2 & & 1 & & 4 & 2 & & 8 & & & & 1 & 21 & 13 \\
\hline Abyssocythere & & & & & 1 & 1 & & & 1 & 3 & 8 & 2 & 5 & 2 & & 4 & 9 & & 24 & & & 60 & 22 \\
\hline Acanthocythereis & & & & & & 6 & 1 & & & & 1 & & & & 9 & & & & & & & 17 & 4 \\
\hline Reticuloechinocythereis & & & & & & & 2 & & 2 & & 2 & 2 & 2 & 2 & & & 5 & & 17 & & & 34 & 12 \\
\hline Rectangulocythereis & & & & & & & 2 & & & & & & & & & & & & & & & 2 & 1 \\
\hline Ambocythere & & & & & & 1 & & & & & & & & & 1 & & 1 & & & & & 3 & 1 \\
\hline Agrenocythere & & & & & & & 1 & & & 1 & 3 & 1 & & 2 & & 3 & 2 & & & & 1 & 14 & 11 \\
\hline Brachycythere & & & 1 & & & & & & 1 & & 1 & 1 & & 1 & 1 & & 1 & & 2 & & 8 & 17 & 13 \\
\hline Henryhowella & & & & & 1 & & & & & 4 & 2 & & 5 & 6 & 19 & & 4 & & 8 & 10 & 29 & 88 & 28 \\
\hline Poseidonamicus & & & & & & & & & & 7 & 11 & 4 & 3 & 9 & 46 & 12 & 46 & 3 & 60 & 41 & 111 & 353 & 51 \\
\hline Thalassocythere & & & & & & & & & 3 & 2 & & & & & 7 & 4 & 7 & & 6 & 1 & 9 & 39 & 18 \\
\hline Bradleya & & & & & & & 1 & & & 1 & & & & 2 & 6 & 1 & & 3 & 4 & 2 & 9 & 29 & 16 \\
\hline Pelecocythere & & & & & & & & & & & 2 & & 1 & & 2 & & & & 1 & 1 & 3 & 10 & 8 \\
\hline Echinocythereis & & & & & & & & & & & & & & & & & & & & & 5 & 5 & 4 \\
\hline Suhmicythere & & & & & & & & & & & & & 1 & 1 & & & & & 2 & & 2 & 6 & 6 \\
\hline Pseudocythere & & & & & & & & & & & & & 1 & 1 & & & & & 2 & & 2 & 2 & 1 \\
\hline
\end{tabular}




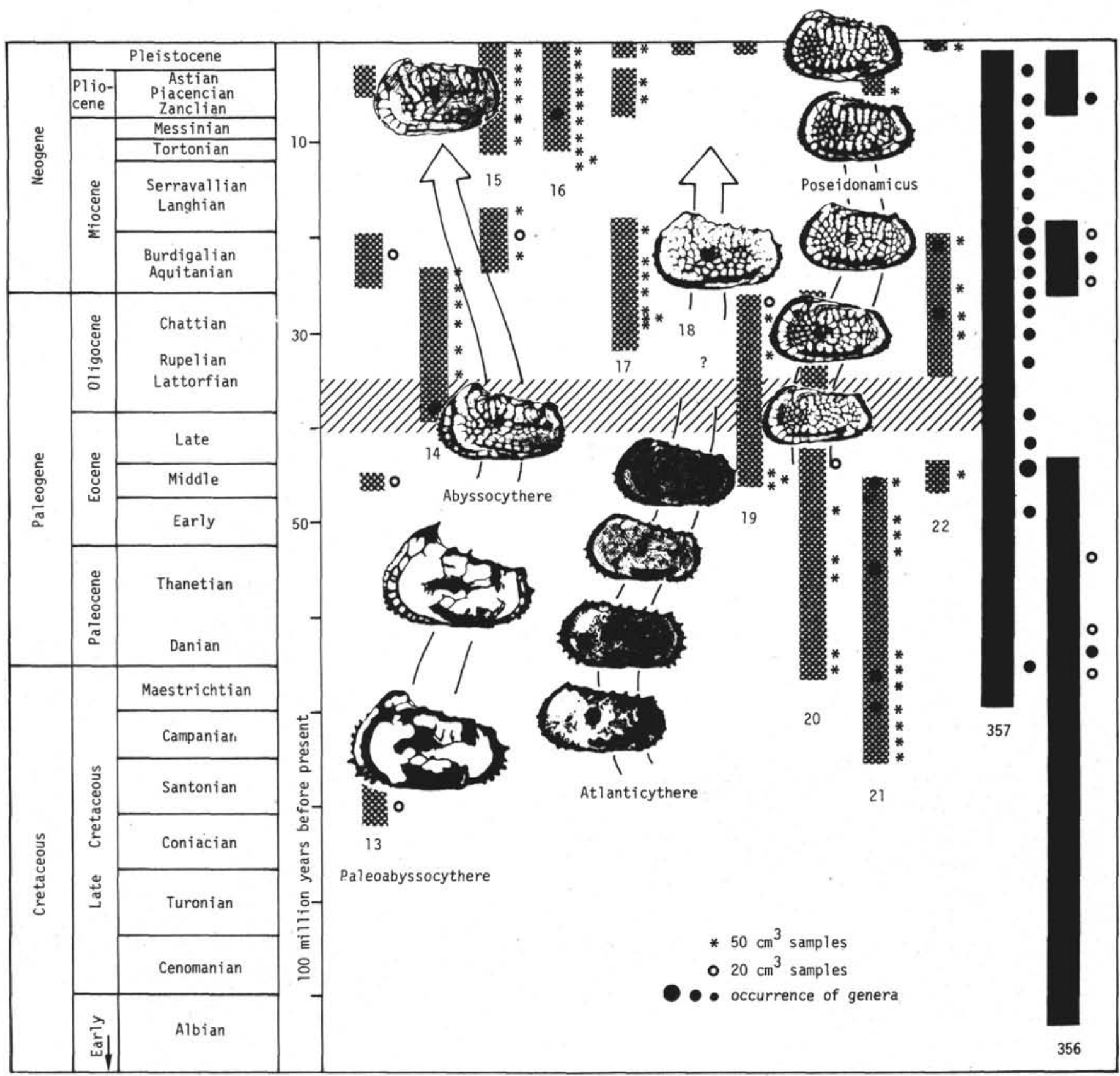

Figure 2. Phyletic lineages of the deep-sea ostracode genera Abyssocythere, Paleoabyssocythere, Atlanticythere, and Poseidonamicus as found in the cores of DSDP Sites 13-22 (half-tone) of Leg 3, and Sites 356 and 357 of Leg 39 of the South Atlantic (modified after Benson, $1975 a, b)$. Note the increase in reticulation with the formation of the psychrosphere $38-40 \mathrm{~m}$. y. B.P. Also note the common occurrence of these important deep-sea ostracodes at Site 357 from Cretaceous onward.

diversity indicates depths greater than 500 meters (Benson, 1975a). Even where as many as 300 specimens were found (often in samples of Sites 21A and 22), there were less than 12 species. Shallow faunas, unless they are in restricted marginal conditions, usually have two to three times as many species. The older ostracode taxa are easily traceable into the modern psychrospheric genera. This is very significant as most of these taxa are not known from shallow-water records. The psychrospheric faunas of the late Paleogene contain genera now typical of lowermost bathyal and abyssal depths. Cytherella, Bairdia, Krithe, and the "bythocyprids," although not identifiable as species in these cores, continue from the Campanian to the Recent. In no way could these ostracode faunas be considered typical of shallow seas.

\section{TESTING ENVIRONMENTAL HYPOTHESES}

This report has remained general. It is intended as a preliminary study of Sites 356 and 357 . Yet changes in 
the ostracodes clearly support certain hypotheses about the origins of the Rio Grande Rise and São Paulo Plateau while contesting others. The conclusions are as follows:

1) Cold deep-water faunas begin in the Oligocene. The ostracodes clearly show the origin of a new and colder ocean system (the psychrosphere) after about 3840 m.y. B.P. This trend is worldwide (Benson, 1975b). There are no indications of the invasion of northern faunas; much of the fauna began in situ and some came from species descending down the Argentine slope.

2) Subsidence in the Cretaceous. The ostracodes are deep ( 800 to $1000 \mathrm{~m}$ minimum) in the Danian of Site 357 (different faunas of $500 \mathrm{~m}$ or less are known from Argentina) and have been deep without noticeable change since the Campanian as shown in Site 22. The waters of the restricted and formative South Atlantic of the later Cretaceous and early Paleogene may have been warm throughout their depth (temperatures higher than $10^{\circ} \mathrm{C}$ ), but were no shallower than 800 meters and probably deeper.

3) Subsidence in comparison with the Sclater et al. curve. It has been suggested, from the Summary and Conclusions of the shipboard report, that if the Sclater curve were used for comparison, one could retrodict a rising sea floor into the past to the point where the Rio Grande Rise would have been a subaerial plateau 2100 meters above sea level. The ostracodes of Sites 21A, 356 , and 357 do not show any time, dating back to about 75 m.y. B.P., wherein shallow faunas were present. It might be argued that the surface topography of such a Rio Grande Archipelago may have also included deep-water troughs. If so, the sites were in these troughs. The ostracodes could only be used as evidence of such troughs, if they had freely circulating bottom waters, but not of shallowing. In the case of Rockall Bank (Benson, 1970), such a history was indeed evident, but not here.

I have not examined the Santonian-Coniacian ostracodes of Leg 39, but I have studied those of Leg 3 extensively. They are deep water. Their co-occurrence with Inoceramus causes no conflicts in interpretation. Inoceramus is also "deep-sea" as described by Kauffman (1976) from Site 317A of the central Pacific (Manihiki Plateau). In Site 357 Inoceramus most likely represents an in situ occurrence of a normal bathyal fauna, without the need for planktonic or allochthonous origins (Kauffman, personal communication). Therefore, the long-term depth interpretations suggested by the microfaunas (benthonic foraminifera and ostracodes) is not refuted by the presence of the macrofossil assemblage.

\section{SYSTEMATIC PALEONTOLOGY}

The following abbreviated descriptions are of new taxa represented in Sites 21A, 22, 356, and 357. The specimens illustrated on Plates 1 and 2 are from Sites 21, 21 A, and 22 where larger populations were found and preservation was better. These descriptions (see SylvesterBradley and Benson, 1971, for terminology) are intended to validate the names and give information for preliminary identifications.

Subclass OSTRACODE Latrielle, 1806

Order PODOCOPIDA Pokorný, 1953
Superfamily CYTHERACEA Baird, 1850

Family TRACHYLEBERIDIDAE Sylvester-Bradley, 1948

\section{PALEOABYSSOCYTHERE, new genus}

Type-species: Paleoabyssocythere cenozoica Benson, new species. Diagnosis: Distinguished from Abyssocythere by the absence of a levatum in the anteromedian region of the reticulum, the presence of an extremely "eared" anterodorsal margin. The general suppression or lack of primary reticulation and the nodose development of the ventrolateral "ridge" complex. The hinge tends to be lobodont with a strongly lobed anterior booth on the right valve.

Remarks: This genus contains a series of species beginning in the Cretaceous with a massive, nodose, poorly defined foveolate carapace surface, an angulate dorsal ridge, and a massive anteromarginal rim. It becomes more reticulate in the Paleogene with more strongly differentiated regions including the dorsal bullar series, a higher muscle-scar node, an attenuated ocular ridge but not a levatum. There are many definable stages of the organization from a finely pitted surface, into secondary reticulation, then rising into a primary reticulum. Reference to the original descriptions of Abyssocythere Benson, 1971, will provide additional comparisons.

Age and distribution: Found worldwide in sediments of late Cretaceous and Paleogene age, but known best from the South Atlantic.

\section{Paleoabyssocythere cenozoica Benson, new species} (Plate 2, Figure 7)

Holotype: USNM 190285; Plate 2, Figure 7. Designated typespecies.

Description: Ocular ridge sharply attenuated, anteromarginal rim subreticulate, reticulum generally undifferentiated but beginning to form from secondary reticulation some elements of the dorsal bullar series peaked, the gamos ridge evident; no reticulation in the ventromarginal ridge area.

Remarks: Differs from $P$. cretacea Benson by the elevation of the gamos ridge, increased reticulation, and alate ocular ridge.

Type-locality: Sample 21A-3-4, 50-56 cm. Thanetian (upper Paleocene).

Distribution: Found in upper Paleocene of Sites 21 and 21A; Samples 21-2-4, 50-56 cm and 21A-3-4, 50-56 cm.

\section{Paleoabyssocythere cretacea Benson, new species} (Plate 2, Figure 8)

Holotype: USNM 190168; Plate 2, Figure 8.

Diagnosis: Ocular ridge subdued although known also to be spinose within a single population, surface lumpy with fine and closely spaced foveolae except on the large bullae or the marginal rims, no gamos ridge.

Remarks: This species is the massively structured predecessor of $P$. cenozoica. Its features are much more crudely defined, although some suggestion of reticular ridge formation is evident.

Type-locality: Sample 21-6-4, 53-59 cm. Campanian.

Distribution: Found at the type-locality throughout Cores 5 to 8 but especially in Core 6.

\section{ATLANTICYTHERE, new genus}

Type-species: Atlanticythere maestrichtia Benson, new species. Diagnosis: Distinguished from other nonreticulate trachyleberids by well-defined, almost equally rounded anterior and posterior marginal rims, an open foveolate to secondarily reticulate surface with small but prominent pore-conuli. Hinge holamphidont; interior trachyleberid.

Remarks: The lateral outline, especially the posterior, is somewhat bradleyid as opposed to being drawn out. It bears some resemblance to Cretaceous species of Oertliella (Pokorný, 1963), although not reticulate. The pore-conuli of the posteromedian region join to form a short median ridge in younger forms. This with the addition of reticulation seems to be one traceable line of phyletic development (see Plate 1, Figures 7 and 8) into the Paleogene and Neogene. Another line is traceable into a dominantly spinose group.

Distribution: Known primarily from the Cretaceous and Paleogene of the South Atlantic. 


\section{Atlanticythere maestrichtia Benson, new species} (Plate 2, Figure 3)

Holotype: USNM 190166; Plate 2, Figure 4. Designated typespecies.

Diagnosis: Distinguished from other species of the genus by the open foveolate surface and distinct, restricted pore-conuli. No posteromedian ridge is present. Without secondary spines

Remarks: Variation within the species seems to be limited to the degree of roughness of the general surface and the development of marginal rise. Some populations seem dominantly smooth, but upon cleaning show an increase in foveolation. Also the muscle-scar node may become multibullate or remain relatively simple. The positions of the pore-conuli are constant, though they may increase in prominence, especially in the anterior. Campanian predecessors have no marginal rims.

Type-locality: Sample $21-4-4,60-66 \mathrm{~cm}$. Maestrichtian.

Distribution: Upper Cretaceous of the South Atlantic.

\section{Atlanticythere murareticulata Benson, new species}

(Plate 2, Figure 3)

Holotype: USNM 190306; Plate 2, Figure 3.

Diagnosis: Distinguished from other species of the genus by the organization of foveolate into secondary reticulation with some primary reticulation and conjunctive spines and the joining of the posteromedian pore-conuli into a short ridge.

Remarks: Variations of the initial reticular development characterize this species during the Paleogene ranging from strongly foveolate in Thanetian forms to subreticulate lower Eocene forms. These precede $A$. eocenica Benson, $\mathrm{n}$. sp. which has only primary reticulation.

Type-locality: Sample $21 \mathrm{~A}-1-4,50-56 \mathrm{~cm}$. Lutetian.

Distribution: Lower Paleogene of the South Atlantic.

\section{Atlanticythere? eocenica Benson, new species}

(Plate 1, Figure 7)

Holotype: USNM 190307; Plate 1, Figure 7.

Diagnosis: Distinguished from other species of the genus by a more rugose appearance and primary reticulation without either secondary reticulation or foveolation.

Remarks: Changes in outline or shape and an increased grossness in ornamentation suggest enough difference to question the generic assignment. This species and $A$. ? neogenica Benson, $\mathrm{n}$. sp. may be considered later as generically distinct.

Type-locality: Sample 22-5-2, 50-56 cm. Lutetian.

Distribution: Paleogene of the South Atlantic.

\section{Atlanticythere? neogenica Benson, new species}

$$
\text { (Plate 1, Figure 8) }
$$

Holotype: USNM 190300; Plate 1, Figure 8.

Diagnosis: Distinguished from other species of the genus by a well defined primary reticulation spread over all of the surface; without nodes or bullae.

Remarks: Possibly the penultimate development of the Atlanticythere lineage, assuming that yet undiscovered gross reticulate stages follow. The posteromedian ridge is noticeable, but tends to be absorbed by the reticulation.

Type-locality: Sample $22-2-4,50-56 \mathrm{~cm}$. Aquitanian.

Distribution: Thus far known only from the lower Miocene of the South Atlantic.

\section{Atlanticythere? prethalassia Benson, new species

$$
\text { (Plate 2, Figure 1) }
$$

Holotype: USNM 190297; Plate 2, Figure 1.

Diagnosis: Distinguished by its secondary spinosity, among the primary pore-conuli, and secondary reticulation.

Remarks: It is not certain whether this is a morphotype or a developing species. It is associated in the same assemblage as $A$. maestrichtia, without apparent morphologic transition. Although it is common, it is named here with some doubt about its relationship to the development of the reticulate species.

Type-locality: Sample $21-5-3,50-56 \mathrm{~cm}$. Maestrichtian.

Distribution: Upper Cretaceous of the South Atlantic.
Genus ACANTHOCYTHEREIS Howe, 1963

Acanthocythereis? presequenta Benson, new species (Plate 2, Figure 5)

Holotype: USNM 190283; Plate 2, Figure 5.

Diagnosis: Distinguished by its very subdued to missing primary reticulation and clavellate or club-like pore-conuli.

Remarks: Only a few of the principal pore-conuli are present as compared with A.? subsequenta, which has a complete set. The generic assignment is quite problematical.

Type-locality: Sample $21-2-4,44-50 \mathrm{~cm}$. Thanetian.

Distribution: Known only from the Paleocene of the South Atlantic.

Acanthocythereis? subsequenta Benson, new species

(Plate 2, Figure 6)

Holotype: USNM 190290; Plate 2, Figure 6.

Diagnosis: Distinguished by its delicate primary reticulation, sharp cardinal angles, clavate and castellate pore conuli, and accessory conjunctive spines.

Remarks: This species seems to be a more spinose developmental stage of $A$. ? presequenta. The generic assignment is problematical.

Type-locality: Sample 21A-1-4, 50-56 cm. Lutetian.

Distribution: Known only from the Paleocene of the South Atlantic.

Genus PHACORHABDOTUS Howe and Laurencich, 1958

Phacorhabdotus subtridentus Benson, new species (Plate 1, Figure 2)

Holotype: USNM 190315; Plate 1, Figure 2.

Diagnosis: Distinguished by absence of an anterior and posterior marginal ridge and subdued posterior longitudinal ridges. Poreconuli are absent, although the pores are evident.

Remarks: This species is about the same in carapace size as the type species $P$. texamus from the Pecan Gap Chalk (Campanian?), but without the well-defined ornament of the margin and ridges. It is also much more subdued in appearance than $P$. simplicatus (Reuss) of Coniacian age as shown by Pokorný, 1963. Campanian variants in South Atlantic have even less well developed ridges.

Type-locality: Sample 21A-3-4, 50-60 cm. Thanetian.

Distribution: From the late Cretaceous and Paleogene og the South Atlantic.

\section{REFERENCES}

Benson, R.H., 1970. Preliminary report on the ostracodes of Holes 117 and 117A. In Laughton, A.S., Berggren, W.A., et al., Initial Reports of the Deep Sea Drilling Project, Volume 12: Washington (U.S. Government Printing Office), p. 427-432.

1971. A new Cenozoic deep-sea genus, Abyssocythere (Crustacea, Ostracoda, Trachyleberidea) with descriptions of five new species: Smithsonian Contrib. Paleobiol., v. 7, p. 25.

1972. The Bradleya Problem, with descriptions of two new psychrospheric ostracode genera, Agrenocythere and Poseidonamicus (Ostracode: Crustacea): Smithsonian Contrib. Paleobiol., v. 12, p. 138.

1974. Preliminary report on the ostracodes of Leg 24. In Fisher, R.L., Bunce, E.T., et al., Initial Reports of the Deep Sea Drilling Project, Volume 24: Washington (U.S. Government Printing Office), p. 1037-1043.

1975a. Morphologic stability in Ostracoda: Am. Paleontol. Bull., v. 65 , p. $13-45,23$ text-figs. , 1975b. The origin of the psychrosphere as recorded in changes of deep-sea ostracode assemblages: Lethaia, v. 8, p. $69-83$.

Bertels, A., 1973. Ostracodes of the type locality of the lower Tertiary (lower Danian) Rocanian Stage and Roca Formation of Argentina: Micropaleontology, v. 19, p. 308-340. 
1974. Upper Cretaceous (lower Maestrichtian?) ostracodes from Argentina: Micropaleontology, v. 20, p. 385-397.

1975. Ostracode ecology during the upper Cretaceous and Cenozoic in Argentina: Am. Paleontol. Bull., v. 65 , p. $317-351$.

Brady, G.S., 1880. Report on the Ostracoda dredged by H.M.S. Challenger during the years 1873-1876: Rept. Voyage of H.M.S. Challenger, Zool., v. 1, p. 1-184.

Kauffman, E.G., 1976. Deep-sea Cretaceous macrofossils: Hole 317A, Manihiki Plateau. In Jackson, E.D., Schlanger, S.O., et al., Initial Reports of the Deep Sea Drilling Project, Volume 33: Washington (U.S. Government Printing Office), p. 503-535.
Maxwell, A.E., et al., 1970. Initial Reports of the Deep Sea Drilling Project, 3 (U.S. Government Printing Office, Washington, D.C.): p. 806.

Pokorný, V., 1963. The Revision of Cythereis ornatissima (Reuss, 1846) (Ostracode, Crustacea). Roz. Ceskoslov. Akad. Ved., 73: 3-59, 7 pls.

Shackleton, N.J. and Kennett, J.P., 1975. Late Cenozoic oxygen and carbon isotopic changes in DSDP Site 284; implications for glacial history of the northern hemisphere and of Antarctica. In Kennett, J.,P., Houtz, R.E., et al., Initial Reports of the Deep Sea Drilling Project, Volume 29: Washington (U.S. Government Printing Office), p. 801-807.

Sylvester-Bradley, P.C. and Benson, R.H., 1971. Terminology for surface features in the ornate ostracodes: Lethaia, v. 4 , p. 249-286. 
, 


\section{PLATE 1}

Ostracode species from Sites 22, 356, and 357

Figure 1 Cytheropteron testudo Sars, right valve, adult; SEM $\times 160$, length $0.58 \mathrm{~mm}$; USNM 190758; Sample 22-1-3, 50-56 cm, Pleistocene.

Figure 2

Phacorhabdotus subtridentus Benson, n. sp., holotype, left valve, adult female?; SEM $\times 115$, length $0.80 \mathrm{~mm}$; USNM 190315; Sample 21A-3-4, $50-56 \mathrm{~cm}$, Thanetian (Globorotalia velascoensis Zone).

Figure 3 Bradleya dictyon (Brady), left valve, adult female; SEM $\times 90$, length $1.03 \mathrm{~mm}$; USNM 190299; Sample 22-2-4, 50-56 cm, Aquitanian (Globigerinita dissimilis Zone).

Figure $4 \quad$ Bradleya aff. B. dictyon Brady, left valve, adult; SEM $\times 100$, length $0.92 \mathrm{~mm}$; USNM 190302; Sample 22-4-4, 53-59 cm, Chattian (Globigerina ampliapertura Zone).

Figure 5 Poseidonamicus sp., left valve, adult male?; SEM $\times 120$, length $0.77 \mathrm{~mm}$; USNM 190303; Sample 22$4-2,77-79 \mathrm{~cm}$, Chattian (Globigerina ampliapertura Zone).

Figure 6 Agrenocythere hazelae (Bold), left valve, adult male?; SEM $\times 80$, length $1.09 \mathrm{~mm}$; USNM 190301; Sample 22-4-4, 53-59 cm, Chattian (Globigerina ampliapertura Zone).

Figure 7 Atlanticythere? eocenica Benson, n. sp., left valve, adult female; SEM $\times 115$, length $0.79 \mathrm{~mm}$; USNM 190307; Sample 22-5-2, 50-56 cm, Lutetian (Globorotalia lehneri Zone).

Figure 8 Atlanticythere? neogenica Benson, n. sp., holotype, left valve, adult female; SEM $\times 110$, length 0.85 mm; USNM 190300; Sample 22-2-4, 50-56 cm, Aquitanian (Globigerinita dissimilis Zone). 


\section{PLATE 1}
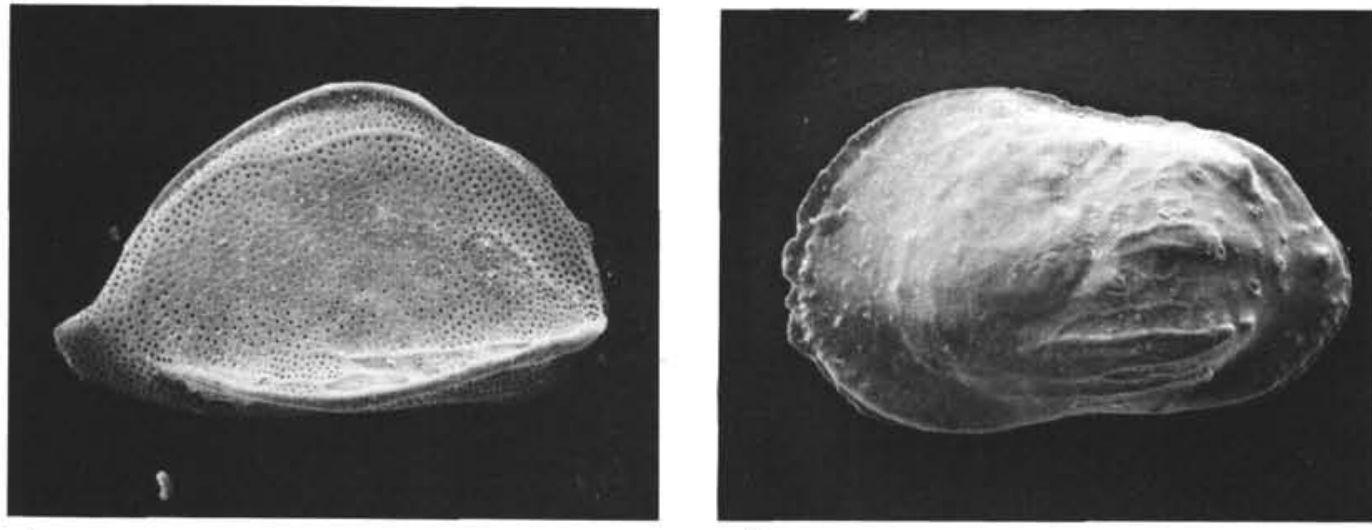

2
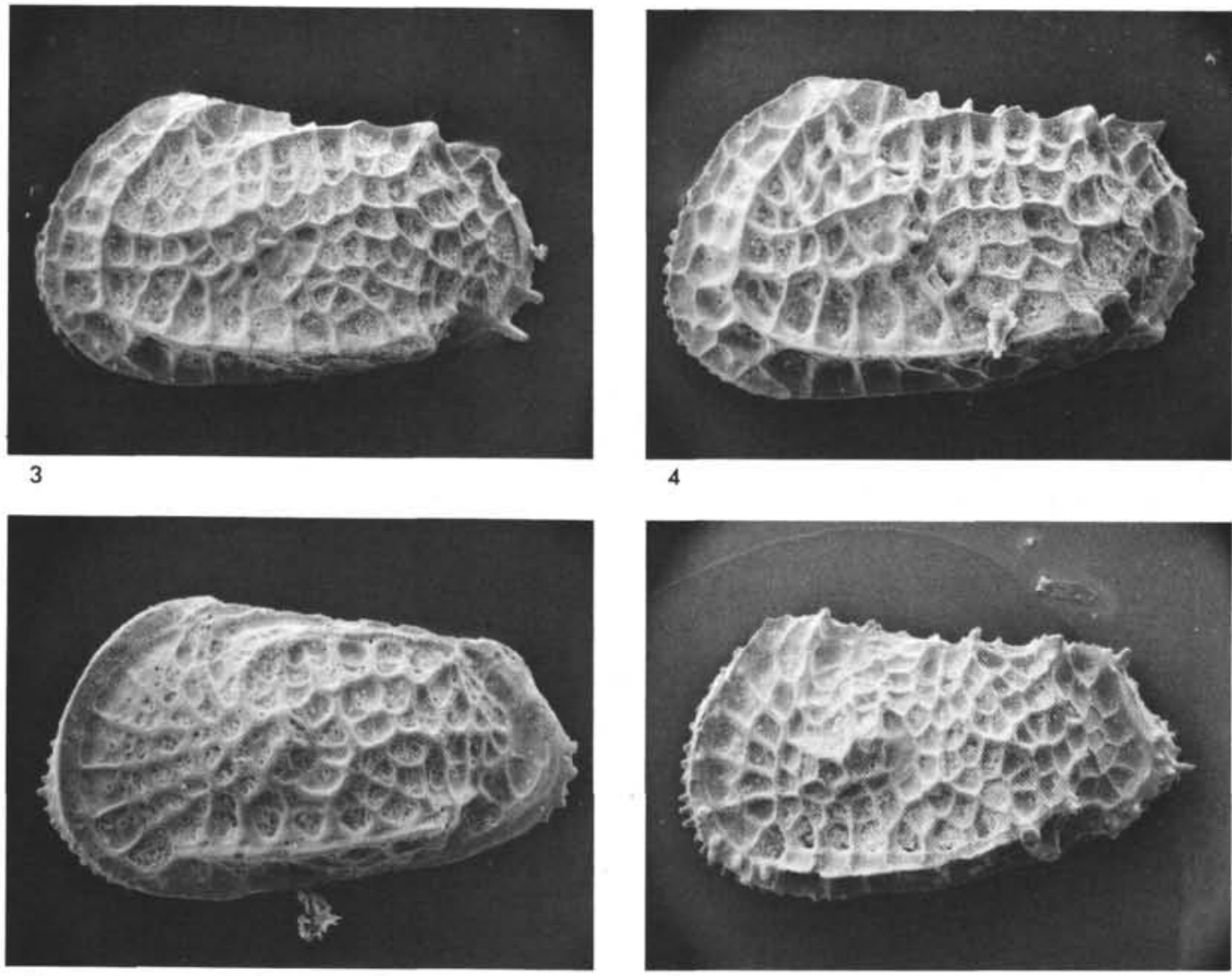

5

6
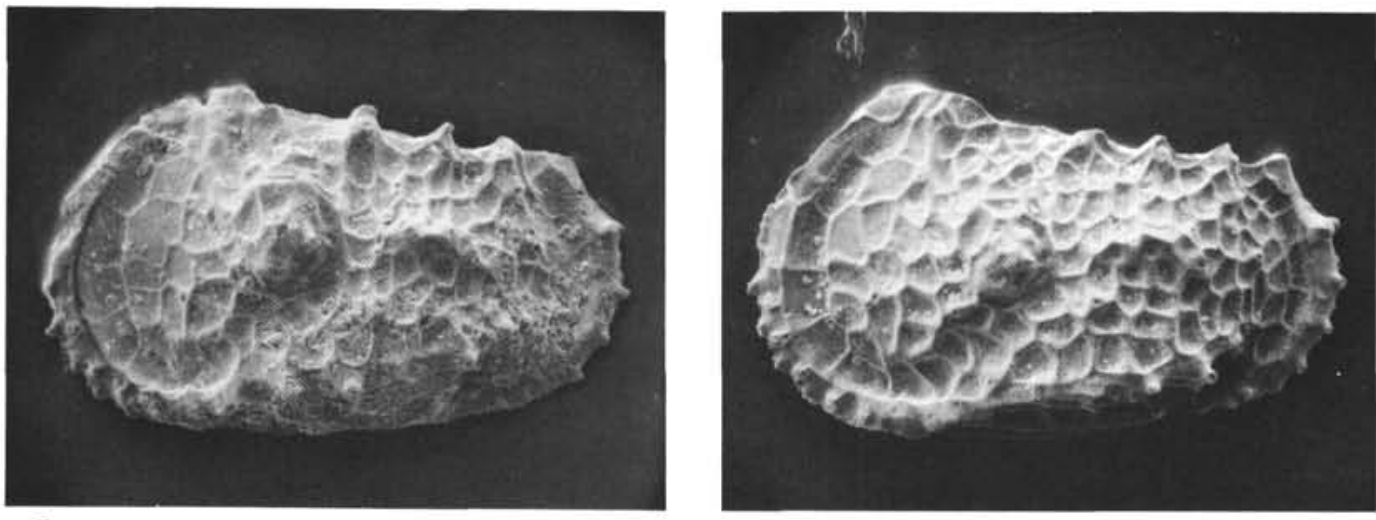

8 
PLATE 2

Ostracode species from Sites 21, 21A, 356, and 357

Figure 1 Atlanticythere? prethalassia, Benson, n. sp., n. gen., holotype; left valve, adult; SEM $\times 90$, length $0.87 \mathrm{~mm}$; USNM 190297; Sample 21-5-3, 50-56 $\mathrm{cm}$, Maestrichtian (Rugotruncana subcircumnoidifera Zone).

Figure 2 Henryhowella asperrima? Reuss, left valve, adult female; SEM $\times 110$, length $0.90 \mathrm{~mm}$; USNM 190757; Sample 21-1-1, 50-56 cm, upper Pliocene.

Figure 3 Atlanticythere murareticulata Benson, n. sp., n. gen., holotype; left valve, adult male; SEM $\times 110$, length $0.87 \mathrm{~mm}$; USNM 190306; Sample 21A-104, $50-56 \mathrm{~cm}$, Lutetian.

Figure 4 Atlanticythere maestrichtia Benson, n. sp., n. gen., holotype and type-species; left valve, adult male; SEM $\times 90$, length $1.03 \mathrm{~mm}$; USNM 190166; Sample 21-4-4, 60-66 cm, Maestrichtian (top of Rugotruncana subcircumnoidifera Zone).

Figure 5 Acanthocythereis? presequenta Benson, n. sp., holotype; left valve, adult; SEM $\times 110$, length 0.84 mm; USNM 190283; Sample 21-2-4, 44-50 cm, Thanetian (Globorotalia velascoensis Zone).

Figure 6 Acanthocythereis? subsequenta Benson, n. sp., holotype; left valve, adult; SEM $\times 140$, length 0.66 mm; USNM 190290; Sample 21A-1-4, 50-56 cm, Lutetian (Globigeraspis kugleri Zone).

Figure 7 Paleoabyssocythere cenozoica Benson, n. sp., n. gen., holotype and type-species; left valve, adult male?; SEM $\times 110$, length $0.80 \mathrm{~mm}$; USNM 190285; Sample 21A-3-4, 50-56 cm, Thanetian (Globorotalia velascoensis Zone).

Figure 8 Paleoabyssocythere cretacea Benson, n. sp., $\mathrm{n}$. gen., holotype; left valve, adult female; SEM $\times 125$, length $0.80 \mathrm{~mm}$; USNM 190168; Sample 21 . 6-4, 53-59 cm, Campanian (Pseudotextularia elegans Zone). 
PLATE 2
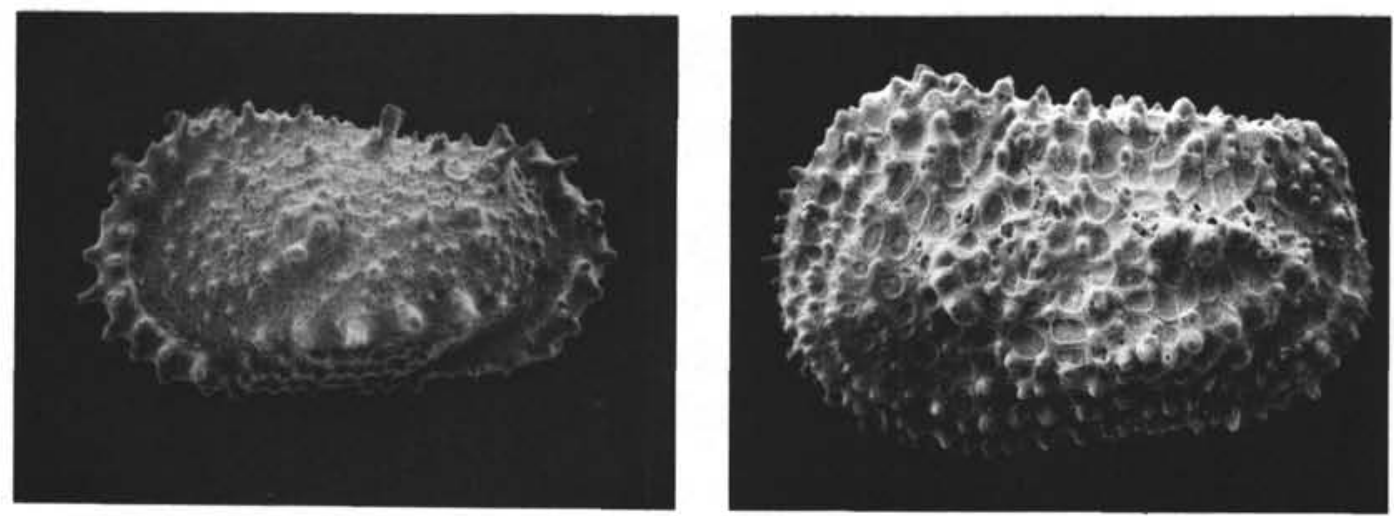

2
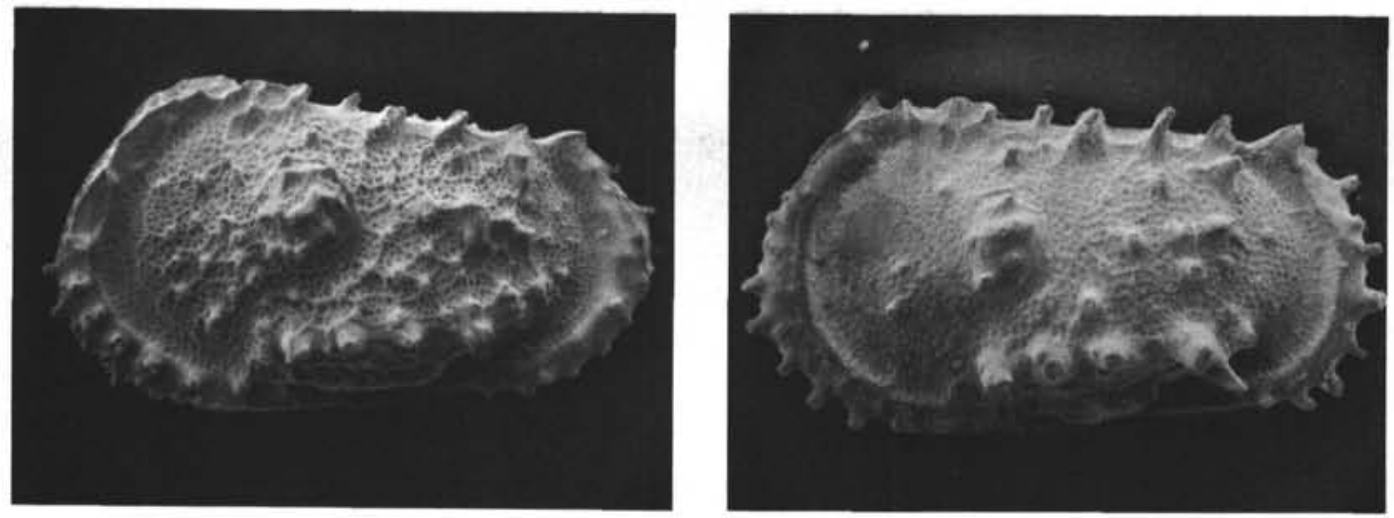

3

4
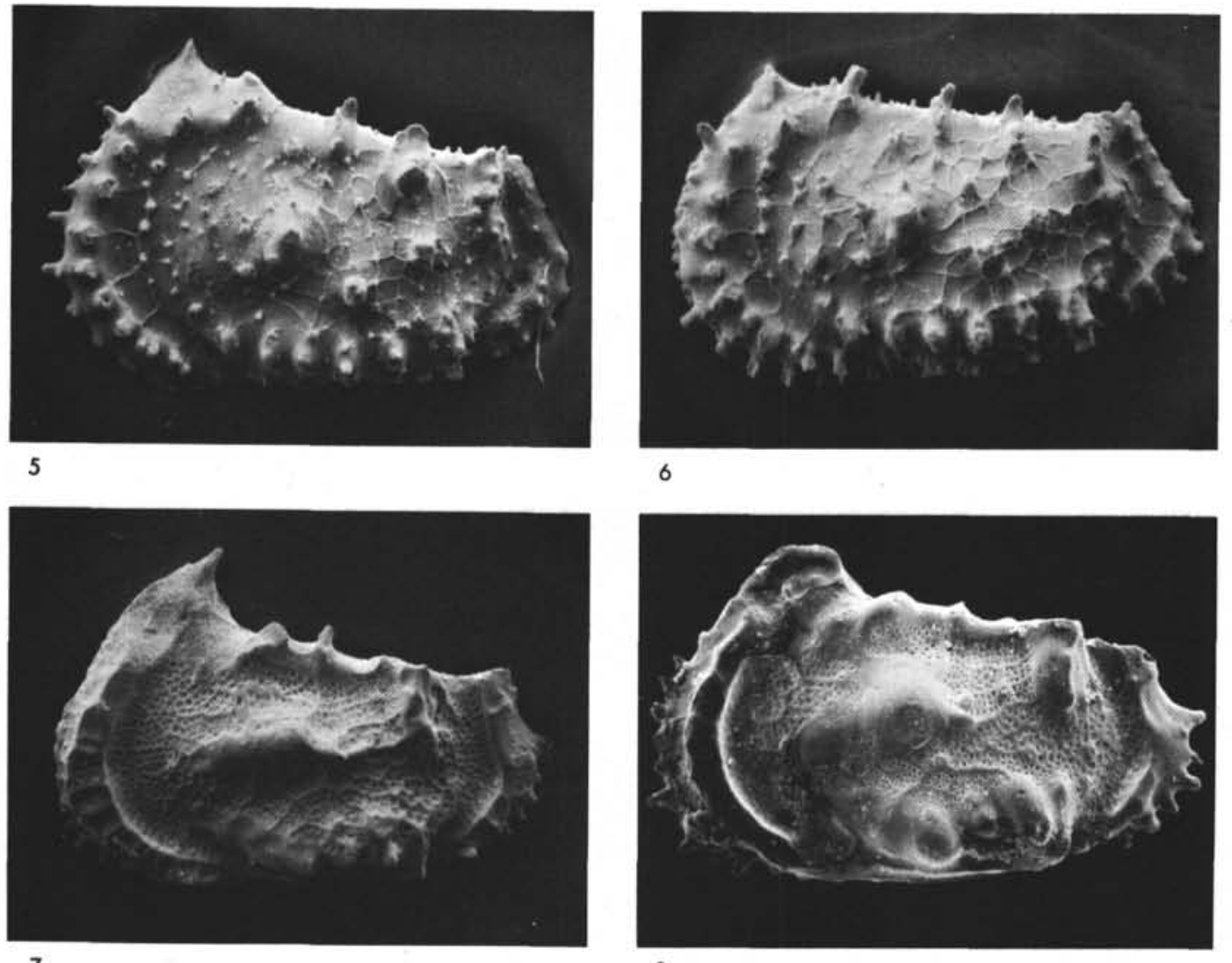

8 